\title{
Correction: Rapid transition to distance learning due to COVID-19: Perceptions of postgraduate dental learners and instructors
}

\author{
Fatemeh Amir Rad, Farah Otaki, Zaid Baqain, Nabil Zary, Manal Al-Halabi
}

The first author's initials appear incorrectly in the citation. The correct citation is: Amir Rad F, Otaki F, Baqain Z, Zary N, Al-Halabi M (2021) Rapid transition to distance learning due to COVID-19: Perceptions of postgraduate dental learners and instructors. PLoS ONE 16(2): e0246584. https://doi.org/10.1371/journal.pone.0246584

An additional affiliation is missing for the third author. Zaid Baqain is also affiliated with School of Dentistry, University of Jordan, Amman, Jordan.

\section{Reference}

1. Rad FA, Otaki F, Baqain Z, Zary N, Al-Halabi M (2021) Rapid transition to distance learning due to COVID-19: Perceptions of postgraduate dental learners and instructors. PLoS ONE 16(2): e0246584. https://doi.org/10.1371/journal.pone.0246584 PMID: 33556131

f open ACCEss

Citation: Amir Rad F, Otaki F, Baqain Z, Zary N, AlHalabi M (2021) Correction: Rapid transition to distance learning due to COVID-19: Perceptions of postgraduate dental learners and instructors. PLOS ONE 16(6): e0253683. https://doi.org/10.1371/ journal.pone.0253683

Published: June 17, 2021

Copyright: @ 2021 Amir Rad et al. This is an open access article distributed under the terms of the Creative Commons Attribution License, which permits unrestricted use, distribution, and reproduction in any medium, provided the original author and source are credited. 